Л. В. Шавлак, Н. І. Буяновська

\title{
ПРО ДЕЯКІ ЛІНГВОМЕТОДИЧНІ ПРОБЛЕМИ СТВОРЕННЯ «ПОСІБНИКА 3 НАУКОВОГО МОВЛЕННЯ ДЛЯ ІНОЗЕМНИХ СТУДЕНТІВ-ПОЧАТКІВЦІВ॥
}

Шавлак Л. В., Буяновська Н. І. Про деякі лінгвометодичні проблеми створення «Посібника з наукового мовлення для іноземних студентів-початківців».

У статті йдеться про дослідження лінгвометодичних проблем, що виникають під час формування фахової мовної компетенції в іноземних студентів на початковому етапі. Подано результати аналізу мовної структури практичних курсів 3 навчальних дисциплін, які викладаються на підготовчому відділенні. Змодельовано типові навчальні тексти, виокремлено основні тематичні ситуації і лексико-граматичний матеріал, що їх обслуговує.

Ключові слова: лінгвістика, методика, лінгвістично-методичні проблеми.

Шавлак Л. В., Буяновская Н. И. О некоторых лингвометодических проблемах написания «Пособия по научному стилю для иностранных студентов начального этапа обучения».

В статье исследуются лингвометодические проблемы, возникающие во время формирования языковой компетенции по специальности в иностранных студентов на начальном этапе. Представлены результаты анализа языковой структуры практических курсов по учебным дисциплинам, которые преподают на подготовительном отделении. Смоделированы типовые учебные тексты, определены основные тематические ситуации и лексико-грамматический материал к ним.

Ключевые слова: лингвистика, методика, лингвистико-методические проблемы. 
Shavlak L. V., Byyanovskaya N. I. On some issues lingvometodicheskih wtiting of the «Handbook of scientific style for foreign students of primary stage of education».

The task research and analysis linhvometodychnyh problems that arise during the formation of professional linguistic competence in foreign students at an early stage. The results of analysis of linguistic structure and practical courses on subjects that are taught in the preparatory department. The analysis made possible to simulate typical academic texts highlight the main subject of the situation and lexico-grammatical material that serves them (express).

Key words: linguistics, methodology, linguistic and methodological problems.

Сучасний етап освітнього процесу в Україні, спрямований на модернізацію вищої освіти, на пошуки новітніх інноваційних технологій, вимагає впровадження більш досконалих методів підготовки майбутніх спеціалістів. У ВН3 нашої країни здобувають вищу освіту іноземні студенти 3 країн Азії, Африки, Латинської Америки, СНД. Метою запропонованої розвідки $є$ дослідження й аналіз лінгвометодичних проблем, які виникають у процесі формування професійної мовної компетенції в іноземних студентів на підготовчому відділенні, що загалом сприятиме створенню посібника з наукового мовлення.

Візьмемо на себе сміливість зауважити, що на сьогодні не існує єдиної цілісної системи викладання української мови як іноземної. Крім того, відсутні і навчальні посібники. Позитивним моментом вважаємо створення єдиного узгодженого концептуального підходу до принципів і методів викладання української мови іноземним студентам, наявність науковометодичних статей, присвячених певним аспектам викладання мови [1, с. $48-54 ; 5$, с. $242-247]$.

Окрему групу складають посібники 3 української мови, мета яких навчити тих, хто володіє російською мовою, вільно говорити українською $[2,4]$. У таких працях практична українська граматика репрезентується в порівнянні з російською, що є продовженням найкращих традицій перших посібників відповідного зразка, започаткованих Ю. О. Жлуктенком, I. Р. Вихованцем, 3. М. Терлаком, А. А. Сербенською та іншими.

Як відомо, сучасні лінгвометодичні концепції визначають фахову й загальну культуру спеціаліста важливою складовою частиною їхньої підготовки. І цілком зрозуміло, що іноземних студентів необхідно навчати, так би мовити, з початкових етапів, наукового стилю як одного 3 аспектів української мови.

Науковий стиль нової української мови і його термінологія складалися впродовж багатьох років, а 3 прийняттям «Закону про мову», 3 утвердженням незалежної української держави почався активний процес вивчення i визначення специфіки наукового стилю як одного зі стилів сучасної української мови [3, с. 31]. Основне призначення наукового стилю - відтворювати здобуті у процесі пошуку між об'єктами дослідження причинно-наслідкові зв'язки, обгрунтовувати гіпотези, роз'яснювати й описувати явища реальної дійсності, систематизувати і репрезентувати 
наукові результати суспільству. Зберігаючи ознаки наукового стилю, кожний його підстиль залежно від комунікативної спрямованості має своє призначення й особливості використання мовних засобів. Так, науковонавчальний підстиль характеризується доступністю викладу матеріалу, послідовним уведенням термінологічної лексики, деякою спрощенністю в доведенні певних знань про предмет, явище, процес і т. ін.

Перед тим, як розпочати процес навчання наукового стилю, на нашу думку, необхідно, по-перше, проаналізувати матеріал тих дисциплін, які викладаються на підготовчому відділенні, по-друге, виокремити для кожної спеціальності зразки текстів і проаналізувати їхні мовні засоби, зокрема й синтаксичні форми, що репрезентують змістовну структуру.

Задля виокремлення найбільш поширених зразків текстів i дослідження мовних засобів оформлення текстової інформації проаналізовано матеріали посібників 3 математики, фізики, інформатики. Основний акцент зроблено на вживаності та частотності мовних засобів, які обслуговують предметно-логічний зміст кожної дисципліни. На основі аналізу змодельовано типові навчальні тексти.

Так, у навчальних посібниках з фізики, де подається інформація про явища, їх зовнішні ознаки, умови й закони існування, зв'язки з іншим явищами і т. ін., найбільш продуктивними є зразки текстів, що засвідчують характеристику предмета, явища, пізнавальної діяльності людини та іiі результати (Кінематика, Механічний рух, Перший закон Ньютона). Тексти 3 хімії, де вивчаються ті чи ті речовини, їхні властивості, хімічні перетворення, стани речей, основні закони хімії, класи неорганічних сполук, типовими $\epsilon$ тексти про процеси, властивості речовин, зв'язок та відношення між явищами, тексти про виробничу і пізнавальну діяльність людини (Азот, Кисень, Горіння, Кипіння, Періодичний закон Д. І. Менделєєва). Тексти з математики дають змогу навчити студентів, задля розкриття суті математичного явища, наводити аргументи, докази, пояснення (Квадратні нерівності та їх системи, Числові нерівності, Теорема Війєта).

Подальшим кроком у розробці цілісної системи викладання української мови і створенні «Посібника 3 наукового мовлення для іноземних студентів-початківців» був аналіз мовного наповнення найтиповіших зразків текстів кожної дисципліни, а згодом виокремлення основних тематичних ситуацій і синтаксичних конструкцій, при цьому враховувалися їхня частотність та універсальність.

Зважаючи на те, що найбільш раціональною $\mathrm{i}$ доцільною $\epsilon$ взаємопов'язана система навчання аудіювання, читання, говоріння та письма, необхідно враховувати специфіку і будову науково-навчальних текстів, їхнє мовне наповнення. Оскільки у викладанні іноземних мов переважає комунікативний метод, який зумовлює зміни в описі мови 3 практичною метою, а функціональна граматика відповідає цим вимогам, 
вважаємо за необхідне використовувати функціональний підхід до викладу граматичного матеріалу в посібнику з наукового мовлення для іноземних студентів. Такий підхід демонструють i автори російськомовних посібників з наукового стилю, як-от Т. Є. Аросєва, 3. І. Борисова та ін.

Зіставлення російськомовного та українськомовного матеріалів переконливо свідчить: маючи спільний об'єкт вивчення, вони істотно відрізняються, ілюструють специфічні лексичні та граматичні особливості, що, власне, передбачає врахування не лише фонетичної, але й граматичної інтерференції. Це можна проілюструвати, наприклад, особливостями наголошування в різних мовах: чотирна́дчяять четь́ринадизать, сімдесят - се́мьдесят; наявністю в українській мові вставних (випадних) голосних звуків [о] [е] (гривня - гривень, добутокдобутка, відсоток - відсотка, кисень - кисню); чергуванням етимологічних [o] [e] 3 [i] у відкритому / закритому складах (корінь кореня, стіл - стола, сім - семи, шість - шести); чергування [о] 3 [е] після шиплячих (иостий - мести, чотири - четвертий) (пор.: рос. шестой, четыре).

3-поміж морфологічних особливостей вирізняються такі, як-от: 1) не завжди збігається рід іменників, наприклад, укр. ступінь (чол. рід) - рос. степень (жін. рід); укр. дріб (чол. рід) - рос. дробь (жін. рід); 2) порядкові числівники у множині мають в українській мові закінчення -i (nерші, другi, mpеті і т. ін.), у російській - -ые, -ьи (первые, вторые, третьи); 3) у кількісних числівниках на -десят в українській мові не змінюється перша частина в непрямих відмінках: n'ятдесят - n'ятдесяти (пор.: рос. nятьдесят - пятидесяти); 4) іменники II відміни чоловічого роду на позначення речовини, процесу мають в українській мові закінчення -y/-ю (кисню, водню, марганцю, вуглецюю, руху, процесу), у російській - -a/-я (кислорода, водорода, марганца, углерода, движения, процесса); 5) у пасивних дієприкметниках минулого часу в українській мові в суфіксах пишеться -н-, -ен-, у російській - -нн-, -енн-) (створений-созданный).

Щодо синтаксичних особливостей, то привертає увагу передусім такий спосіб підрядного зв’язку, як керування, зокрема прийменникове. Наприклад, прийменник по в українській мові, на відміну від російської, використовується значно рідше, перевага надається прийменнику за, подекуди - безприйменниковим конструкціям: обчислити за формулою вичислить по формуле; визначається за формулою - определяется по формуле; визначається ї̈ координатою $x$-определяется по ее координате $x$. Щоправда, прийменник по залишається в конструкціях, якщо йдеться про рух по поверхні: при ковзанні тіла по опорі, рухатися по поверхні.

На думку авторів посібника, основними етапами в засвоєнні особливостей наукового стилю є вироблення навичок читання, аудіювання наукових текстів і письма. Усі ці етапи чітко взаємопов'язані, маніфестуються у процесі запису лекцій. Певна система вправ спрямована 
на навчання правильно записувати відповідний текст, формувати уміння аудіювання, мисленнєво перетворювати текст для його писемної фіксації.

Викладені положення репрезентовані в матеріалах «Посібника 3 наукового мовлення для іноземних студентів-початківців».

\section{Література}

1. Василенко Н. В. Прогнозування порушень орфоепічної реалізації приголосних фонем української мови у вимові арабськомовних носіїв / Н. В. Василенко // Сучасна україністика : наукові парадигми мови, історії, філософії : [зб. наук. праць]; за заг. ред. О. С. Черемської. - Харків : Вид-во ХНЕУ, 2008. - Ч.ІІІ. C.48-54.

2. Зайченко Н. Ф. Практичний курс для іноземців : усне мовлення / Н. Ф. Зайченко, С. А. Воробйова. - К. : Знання України, 2008. - 324 с.

3. Коваль А. П. Науковий стиль сучасної української мови : Структура наукового тексту / А. П. Коваль. - К., 1970. - 312 с.

4. Новицька Л. Т. Вивчаємо українську : [навчальний посібник] / Новицька Л. Т., Поліщук Т. М., Шавшина Н. П. та ін. - К., 1993. - 336 с.

5. Смолінська О. Є. Методичні аспекти вивчення граматики української мови як іноземної / О. С. Смоленська, О. С. Іванців // Сучасна україністика : наукові парадигми мови, історії, філософії : [зб. наук. праць]; за заг. ред. О. С. Черемської. - Харків : Вид-во ХНЕУ, 2008. - Ч.ІІІ. - С.242-247.

Стаття надійшла до редакиії 30.09.2010 р. 